\title{
Venda Language
}

National Cancer Institute

\section{Source}

National Cancer Institute. Venda Language. NCI Thesaurus. Code C154191.

A Niger-Congo Bantu language mainly spoken by the Venda people in the northern part of South Africa's Limpopo Province, as well as by some Lemba people in Zimbabwe. 